\title{
The effects of unsaturated fatty acids on Helicobacter pylori in vitro
}

\author{
S. KHULUSI, H. A. AHMED, P. PATEL, M. A. MENDALL and T. C. NORTHFIELD* \\ Division of Biochemical Medicine, Department of Cellular and Molecular Sciences, St George's Hospital Medical \\ School, Cranmer Terrace, London SW17 ORE
}

\begin{abstract}
Summary. The effects of three unsaturated free fatty acids on Helicobacter pylori growth in vitro was determined. Growth of $H$. pylori in Brucella broth was inhibited in a dose-dependent manner by arachidonic, linoleic and oleic acids. The degree of inhibition at any one concentration was related to the degree of fatty acid unsaturation. Triolein, a triacylglycerol ester of oleic acid did not inhibit growth. Inhibition of $H$. pylori growth was associated with disruption of cell membranes. Incubation with ${ }^{14} \mathrm{C}$ linoleic acid and ${ }^{14} \mathrm{C}$ oleic acid showed incorporation of these fatty acids into $H$. pylori cell mass and phospholipids leading to alteration of the phospholipid composition of the organism. Incorporation was greater with linoleic than oleic acid and this was associated with a greater inhibition of growth. These findings indicate that $H$. pylori is sensitive to unsaturated free fatty acids through their incorporation into phospholipids and membrane destruction. This may have therapeutic implications.
\end{abstract}

\section{Introduction}

The importance of Helicobacter pylori in the pathogenesis of duodenal ulceration is well established..$^{1-3}$ Colonisation of both gastric antrum and duodenum are essential prerequisites to ulceration ${ }^{4,5}$ and eradication of $H$. pylori results in cure of duodenal ulcer disease. ${ }^{1,6}$

Dietary polyunsaturated fatty acids have been implicated in the prevention of peptic ulcers. This is based on epidemiological ${ }^{7}$ and clinical studies, ${ }^{8}$ but the mechanism of protection remains unclear. The antibacterial effect of fatty acids has long been recognised ${ }^{9-11}$ and is believed to be an important factor regulating the distribution and density of colonisation in the lung, ${ }^{12}$ on the skin ${ }^{13}$ and in the gastrointestinal tract. ${ }^{14,15}$

In-vitro studies have examined the sensitivity of different bacteria to fatty acids in relation to the physicochemical properties of both the substances and the organisms. ${ }^{10,16-19}$ Generally, gram-positive bacteria are more susceptible to the damaging effects of fatty acids than gram-negative bacteria. ${ }^{20}$ Both the composition and permeability of the bacterial outer membrane are important factors in this difference. ${ }^{21}$

Received 19 July 1994; accepted 29 Sept. 1994

${ }^{*}$ Correspondence should be sent to Professor T. C. Northfield.
Unsaturated fatty acids tend to be more inhibitory than saturated ones and cis unsaturated isomers are more damaging than trans isomers. ${ }^{17,22}$ The concentration of unsaturated fatty acids also determines their inhibitory effect on bacteria; generally, low concentrations have either growth stimulating or bacteriostatic effects, whereas high concentrations have toxic effects on susceptible organisms. ${ }^{20,23}$

A proportion of bacterial fatty acids are unsaturated whereas others have a cyclic structure, a feature not normally present in eukaryotic cells. Changes in the environment alter the proportions of membrane fatty acids, ${ }^{24-26}$ suggesting that it may be possible to manipulate fatty acid composition and, thus, membrane characteristics.

Arachidonic, linoleic and oleic acids, present in cell membranes as phospholipid components, are the three commonest fatty acids present in biological systems. They have different physicochemical properties and are either part of dietary intake or synthesised by the human body. This study reports the results of investigations into the effects of these three unsaturated fatty acids on $H$. pylori in vitro.

\section{Materials and methods}

\section{Growth in liquid culture}

H. pylori strains from human endoscopic biopsy 
samples were grown in Brucella Broth (Oxoid) supplemented with horse serum $5 \%$ and vancomycin, trimethoprim, cefsulodin and amphotericin $\mathrm{pH} 7 \cdot 4$, at $37^{\circ} \mathrm{C}$ in micro-aerophilic conditions $\mathrm{O}_{2} 5 \%, \mathrm{CO}_{2} 7 \%$, $\mathrm{H}_{2} 8 \%, \mathrm{~N}_{2} 80 \%$; Oxoid gas generating kit and gas jar, Unipath) ${ }^{27}$ in thin-layer, non-shaking containers for 2-3 days. Only those cultures yielding heavy, pure growths were used; bacteria from poorly growing cultures tended to give variable results and were discarded. Three free fatty acids-oleic $(\mathrm{Cl} 8 ; \Delta 9, \mathrm{Cis})$ linoleic $(\mathrm{C} 18 ; \Delta 9,12, \mathrm{Cis})$ and arachidonic acid $(\mathrm{C} 20$; $\Delta 5,8,11,14, C i s)$-at $0 \cdot 05,0 \cdot 1,0 \cdot 5,1 \cdot 0,2 \cdot 0$ and $5 \mathrm{~mm}$ concentrations, and the triacylglycerol of oleic acid, triolein, at 2 and $5 \mathrm{~mm}$ were studied. Slightly opalescent suspensions of these substances in Brucella broth were added to separate cultures of the same strain, containing c. $5 \times 10^{7}$ organisms $/ \mathrm{ml}$ in mid-log growth and were incubated for $48 \mathrm{~h}$. Optical density changes of the cultures at $540 \mathrm{~nm}$ (SP6-450 UV/VIS spectrophotometer; Pye Unicam) and viable count measurements ${ }^{28}$ were used to assess numbers of organisms at 24 and $48 \mathrm{~h}$. All incubations with fatty acids were repeated with six different strains to ensure that the results were reproducible. At $48 \mathrm{~h}, \mathrm{H}$. pylori cells were harvested by centrifugation at $25000 \mathrm{~g}$ for $20 \mathrm{~min}$ and were washed twice in Brucella broth. They were then re-incubated in fresh Brucella broth for a further $24 \mathrm{~h}$ to determine whether any fatty acidinduced effect on growth was reversible.

Because preliminary experiments had shown that changes in $\mathrm{pH}$, incubation temperature and inoculum size all independently altered the sensitivity of $H$. pylori to unsaturated fatty acids, these factors were kept constant in all experiments. The identity of the organisms was confirmed at each stage by Gram's stain, urease and catalase tests. The morphology of the organism and the integrity of the membrane were assessed by light microscopy (Leitz Dialux 20 EB) and by transmission electronmicroscopy (Zeiss EM 900), respectively.

\section{Incorporation of radiolabelled fatty acids}

${ }^{14} \mathrm{C}$ linoleic acid, oleic acid and triolein (fatty acid labelled) were added to separate cultures containing organisms in mid-log growth. After incubation for 24 and $48 \mathrm{~h}, H$. pylori cells were separated from the culture medium by centrifugation at $25000 \mathrm{~g}$ for $20 \mathrm{~min}$ and washed twice with saline. The total incorporation of radiolabelled fatty acid was measured by scintillation counting of the washed cells. $H$. pylori lipids were isolated by the method of Folch et al. ${ }^{29}$ and then separated by thin layer chromatography (TLC) on silica gel G plates $(20 \times 20,250 \mu \mathrm{m}$, Anachem) with a solvent mixture of chloroform:hexane:methanol: acetic acid: water $(12: 7: 4: 3: 0 \cdot 3){ }^{30}$ Free fatty acid and phospholipid bands on chromatograms were visualised by iodine staining and quantified by scintillation counting of the bands collected by scraping.

\section{Fatty acid methyl ester profiles}

The phospholipids extracted from $H$. pylori by the Folch method, ${ }^{29}$ and separated by TLC as described above, were dried under nitrogen and boiled in boron trifluoride $14 \%$ in methanol. ${ }^{31}$ Fatty acid methyl esters were then extracted in hexane, dried under nitrogen and analysed by gas liquid chromatography (GLC) with a DB-23 Megabore 30-m column, with $0.5 \mu \mathrm{m}$ film thickness ( $\mathrm{J}$ and W Scientific, CA, USA) in a GC6000 GLC machine (Vega series 2, ICU 600, Carlo Erba Instruments). Peaks were identified by comparison with the retention times of known standards and the area under the curve was measured to determine the percentage of each fatty acid in the sample.

\section{Results}

\section{Growth in liquid media}

The optical density of liquid cultures related closely to viable counts on chocolate agar plates $(r=0.94$, $\mathrm{p}<0.001)$ thus validating the use of optical density in the measurement of numbers of viable organisms in liquid cultures (fig. 1).

Exponential growth of $H$. pylori in control conditions is shown in fig. 2. In the presence of unsaturated fatty acids growth was inhibited compared to control growth in a dose-dependent manner at 24 and $48 \mathrm{~h}$ (fig. 3). The inhibitory effect of the three fatty acids, at a given concentration, was related to their degree of unsaturation: arachidonic $>$ linoleic $>$ oleic acid. Esterification of oleic acid resulted in the complete loss of its inhibitory effects on $H$. pylori growth.

The diminution in the growth rate of H.pylori in the presence of the highest concentration of oleic acid $(5 \mathrm{mM})$ persisted after incubation for $48 \mathrm{~h}$ in the absence of oleic acid. By contrast, cultures in lower concentrations (0.05-1 $\mathrm{mM})$, produced a small and insignificant inhibition of growth at $24 \mathrm{~h}$, but the growth rate reverted completely to normal by $48 \mathrm{~h}$. Interestingly, growth inhibition by $2 \mathrm{~mm}$ oleic acid was

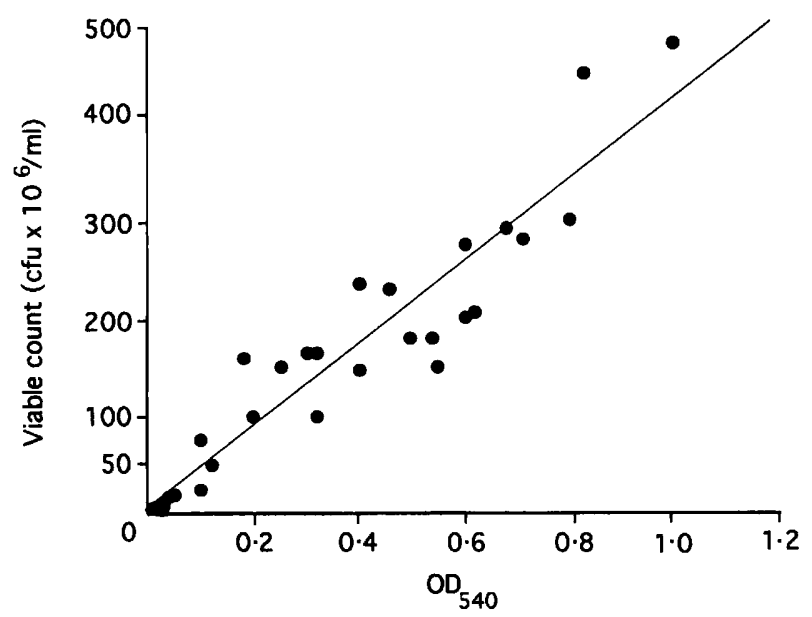

Fig. 1. Relationship between $\mathrm{OD}_{540}$ of cultures and viable counts; $r=0.94, p<0.001$. 


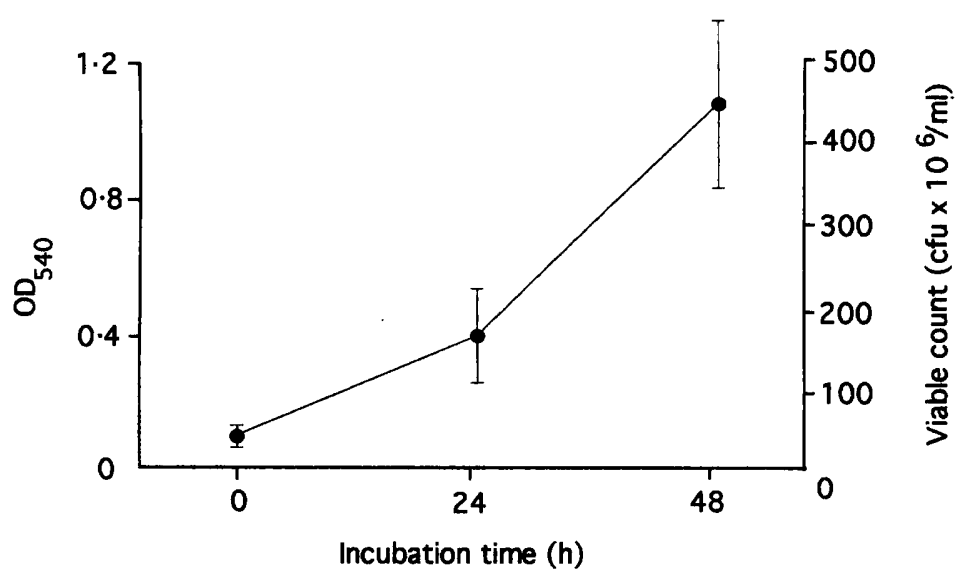

Fig. 2. Growth of $H$. pylori in liquid culture under control conditions.

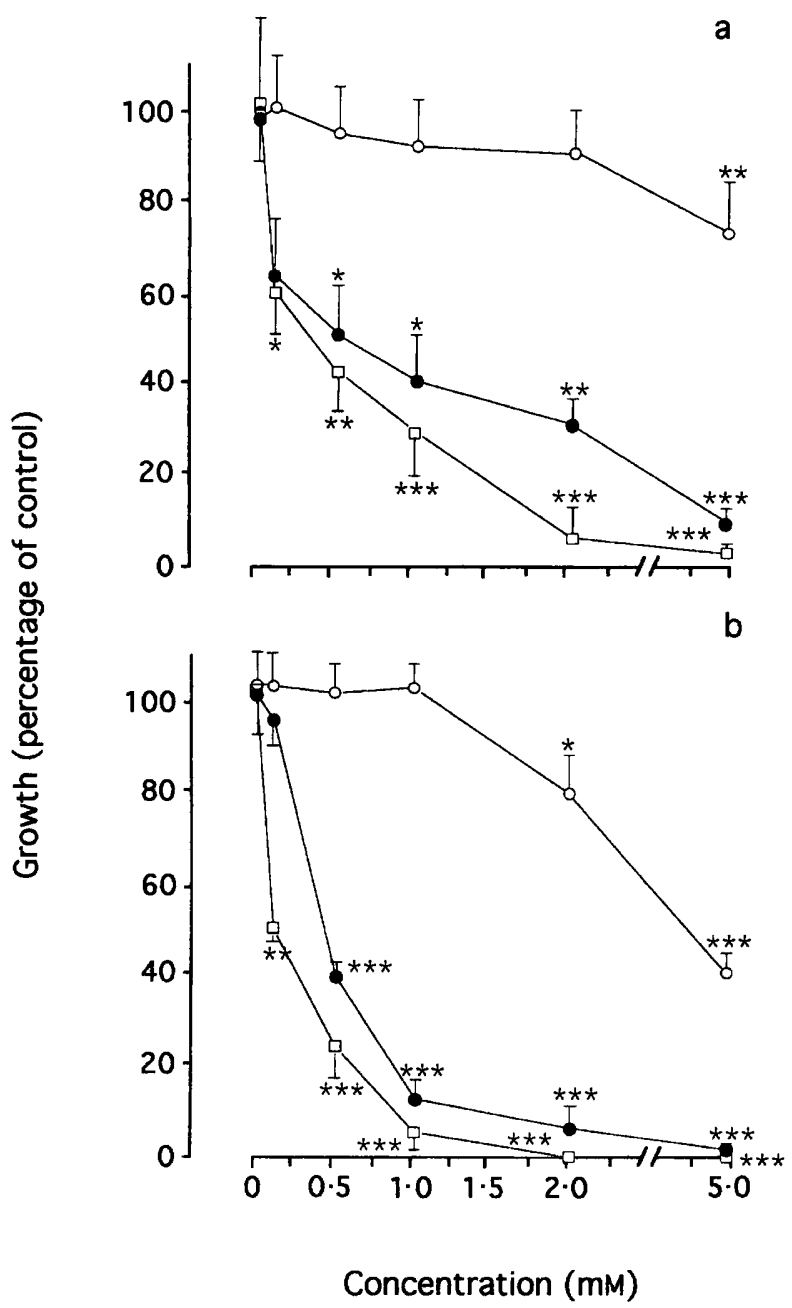

Fig. 3. Relative growth of $H$. pylori to that of control after (a) $24 \mathrm{~h}$ and (b) $48 \mathrm{~h}$ incubation with arachidonic acid $(\square)$, linoleic acid (O) and oleic acid $(\bigcirc) ;{ }^{*} \mathrm{p}<0.05,{ }^{* *} \mathrm{p}<0.01,{ }^{* * *} \mathrm{p}<0.001$ versus control.

reversible at $48 \mathrm{~h}$, with the growth rate returning to that of the control within a further $24 \mathrm{~h}$. Growth inhibited by 0.05 and $0.1 \mathrm{~mm}$ linoleic acid and arachidonic acid was similarly reversible. However, growth inhibition by all higher concentrations of these two fatty acids was not reversible.

\section{Morphology of $H$. pylori}

Light microscopy of cultures grown under control conditions and of those with the higher ( $>90 \%$ of control) growth in the presence of fatty acids showed $H$. pylori cells with normal curved or S-shaped morphology; $<10 \%$ of cells had coccoid forms. Increased proportions of coccoid forms were formed during growth in inhibitory concentrations of all three fatty acids after 24 and $48 \mathrm{~h}$ until, at $<50 \%$ of the control growth, both spiral and coccoid forms of $H$. pylori were sparse and difficult to find.

By electronmicroscopy, cultures with minimal growth inhibition contained predominantly curved or S-shaped organisms. A few had a more rod-like appearance (fig. 4a). The cells from cultures with reduced growth ( $<50 \%$ of the control) showed total loss of the normal curved morphology, fragmentation of the bacterial cell membranes, disruption of protoplasmic cylinders and cell lysis (fig. 4b).

\section{Incorporation of radiolabelled fatty acids}

Incorporation of ${ }^{14} \mathrm{C}$ linoleic and oleic acids into $H$. pylori cells was detected at 2 and $5 \mathrm{~mm}$; however, ${ }^{14} \mathrm{C}$ triolein was not incorporated. At both concentrations there was greater incorporation of linoleic than oleic acid (fig. 5). Folch extraction of $H$. pylori lipids and subsequent TLC separation showed that a proportion of the fatty acids taken up was incorporated into phospholipid. More linoleic acid than oleic acid was incorporated into it (fig. 6).

\section{Fatty acid methyl ester profiles}

$H$. pylori grown under control conditions showed a distinctive fatty acid methyl ester profile (table). Myristic and cyclopropano-nonadecanoic acid were the major component fatty acids and comprised $32 \%$ and $26 \%$ of the total, respectively. Palmitic, stearic, oleic and linoleic acids were also present in significant amounts, each comprising $6-10 \%$ of the fatty acid content of $H$. pylori phospholipid. Smaller contributions $(\leqslant 2 \%$ each) came from lauric, hydroxy- 


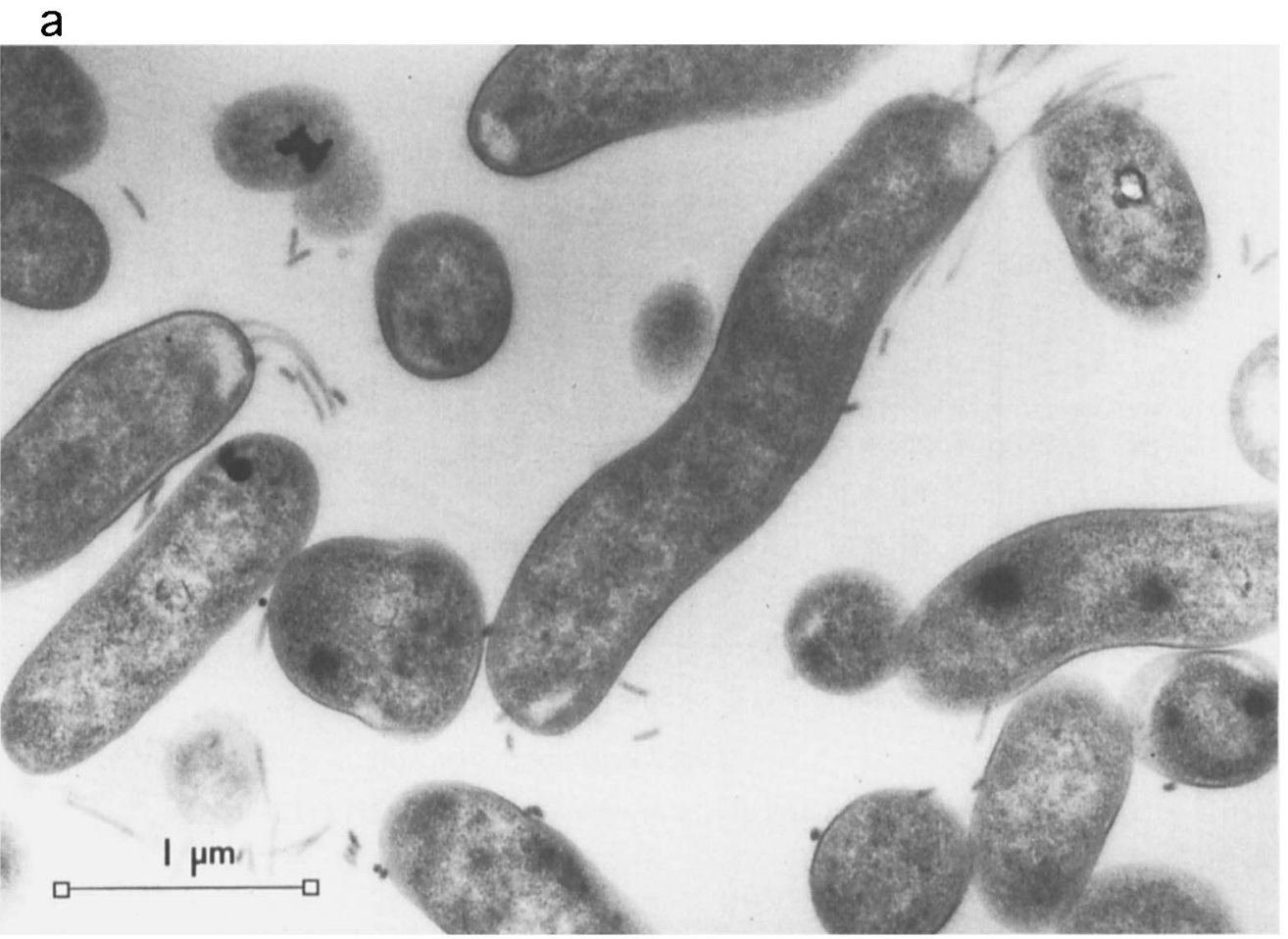

b

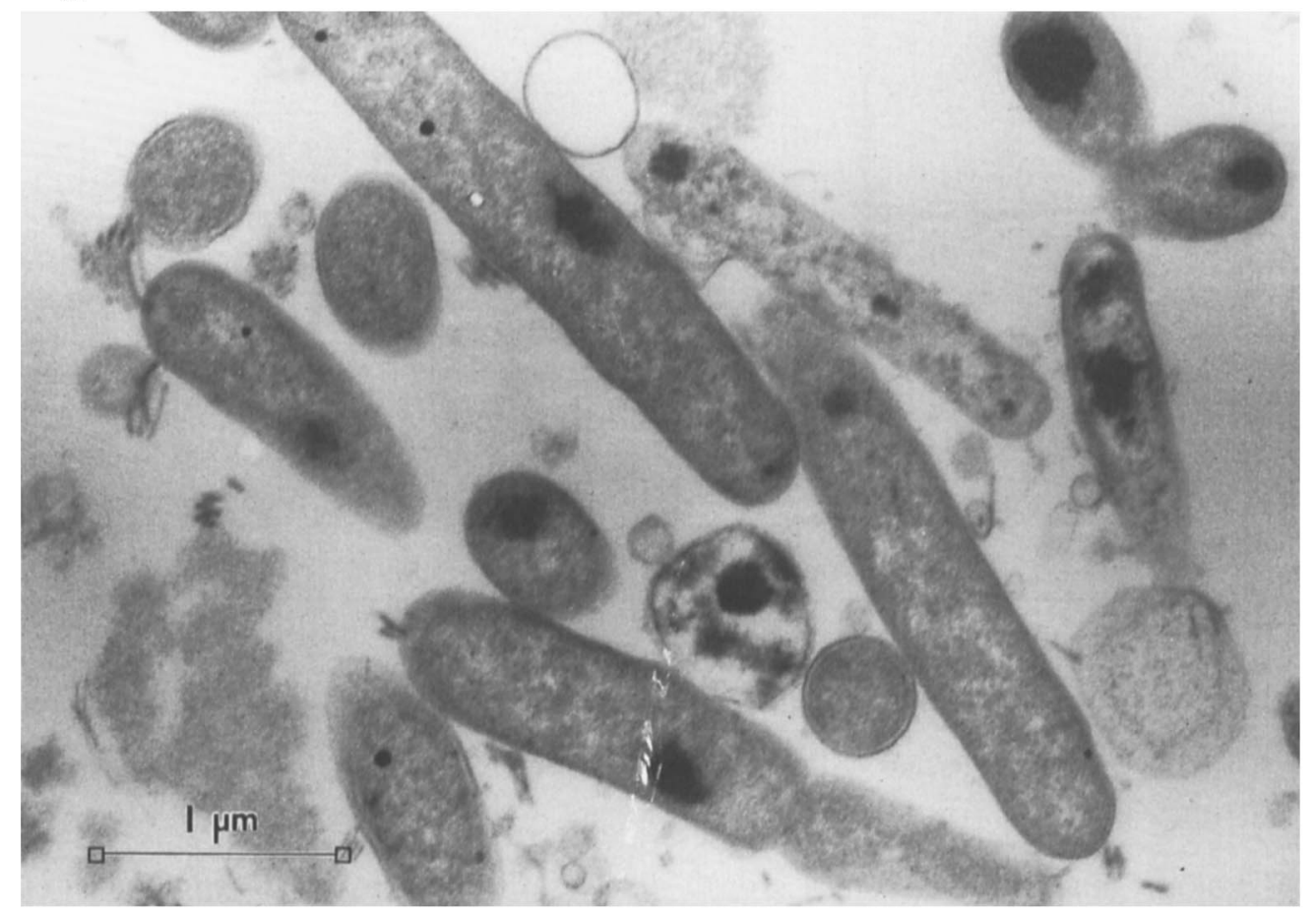

Fig. 4. Thin sections of H. pylori incubated with linoleic acid: (a) $0.05 \mathrm{~mm}$ for $24 \mathrm{~h}$, showing normal organism morphology; (b) $2 \mathrm{~mm}$ for $24 \mathrm{~h}$, showing distortion of the protoplasmic cylinder, and disruption and fragmentation of the cell membranes.

palmitic, linolenic, arachidic, arachidonic and clupanodonic acids, and a further $3 \%$ was in the unidentified fractions. Addition of free linoleic acid or oleic acid ( $2 \mathrm{mM})$ to the culture medium resulted in a greater than two-fold increase in the amount of these fatty acids in $H$. pylori phospholipid, compared to the control (table), but a decrease in its content of myristic and cyclopropano-nonadecanoic acids.

\section{Discussion}

H. pylori growth can be inhibited in vitro by unsaturated fatty acids and the extent of inhibition is related to the degree of unsaturation of the fatty acid. The greatest inhibition was produced by arachidonic acid with four double bonds, followed by linoleic acid with two. The least inhibitory was oleic acid with a 
a
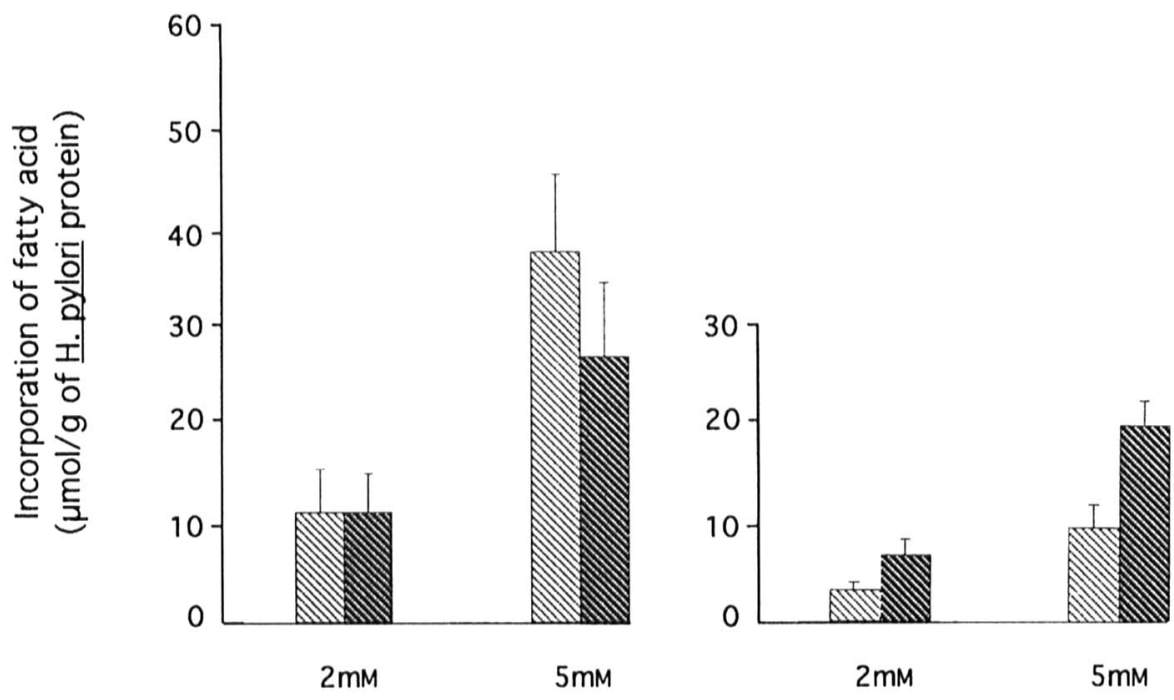

Fatty acid concentration

Fig. 5. Incorporation of (a) linoleic acid and (b) oleic acid into H. pylori cell mass at $24 \mathrm{~h}(\mathbb{8})$ and $48 \mathrm{~h}(\mathbb{\mathbb { N }})$.

a

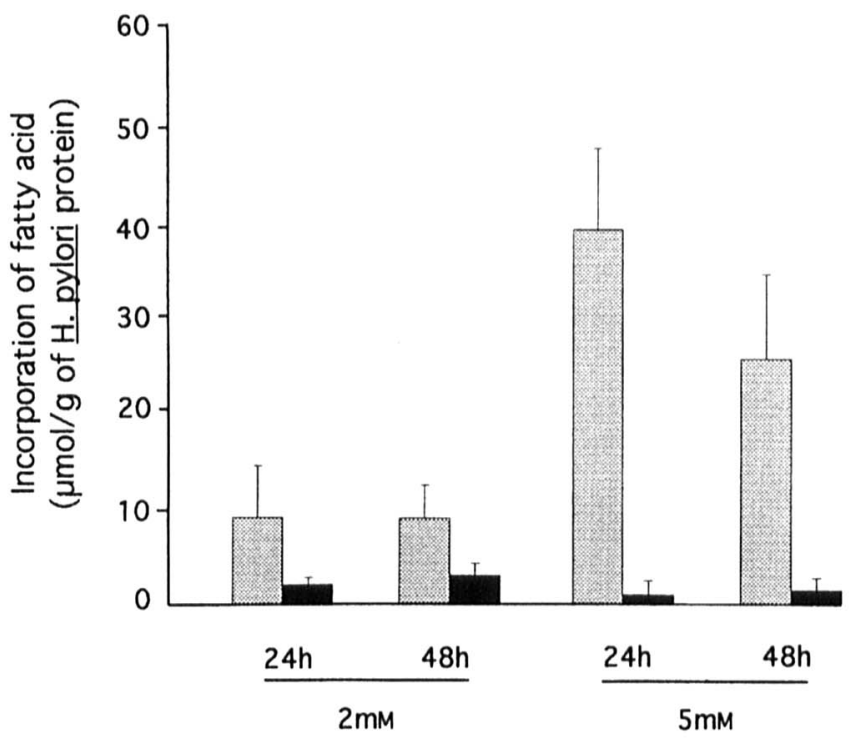

b

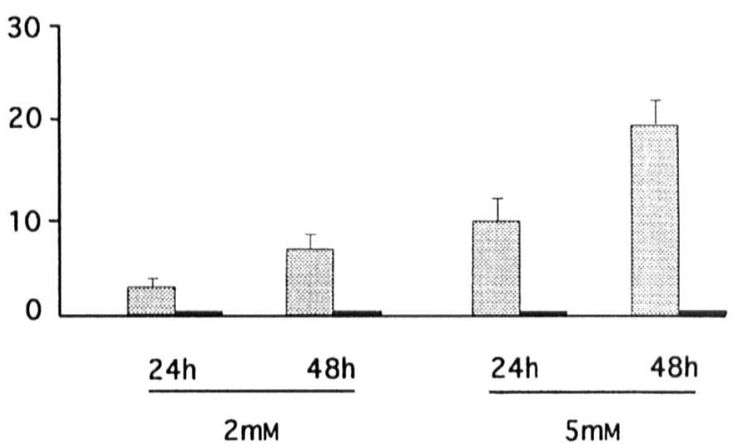

Fatty acid concentration

Fig. 6. Proportion of (a) linoleic acid and (b) oleic acid converted to phospholipid; $\square$, fatty acid; $\square$, phospholipid.

single double bond. Significant inhibition of growth was associated with loss of the normal morphology of the organism, fragmentation and disruption of cell membranes and cell lysis. More pronounced growth inhibition and membrane destruction, as given by linoleic acid rather than oleic acid, was associated with greater incorporation of linoleic acid into $H$. pylori. The incorporation of both linoleic and oleic acids resulted in enhancement of the peaks produced by their respective methyl esters on GLC, indicating that these fatty acids were taken up and utilised in phospholipid synthesis by the organism. This incorporation was also accompanied by a reduction in the levels of other fatty acid constituents. Esterification of oleic acid inhibited its incorporation into $H$. pylori and negated its growth inhibitory effects. These findings suggest that alteration in phospholipid composition as a result of free fatty acid uptake may affect the physicochemical characteristics of $H$. pylori membranes resulting in disturbance of both their structure and function.

An alternative explanation is that the inhibitory effect of fatty acids is related to their chain length, as arachidonic acid has 20 carbon atoms while the other two fatty acids have only 18 . However, this does not explain the difference in effects between linoleic acid and oleic acid. $H$. pylori grown in vitro is sensitive to changes in $\mathrm{pH}$, and fatty acids may produce their 
Table. Fatty acid composition of $H$. pylori under control conditions and comparative data from cultures incubated with oleic and linoleic acids

\begin{tabular}{|c|c|c|c|c|}
\hline \multirow{2}{*}{ Fatty acid } & \multirow{2}{*}{ Structure } & \multicolumn{3}{|c|}{$\begin{array}{l}\text { Percentage composition of } H . \text { pylori } \\
\text { grown with }\end{array}$} \\
\hline & & control broth & oleic acid & linoleic acid \\
\hline Lauric & $\mathrm{C} 12$ & $1 \cdot 3$ & $1 \cdot 2$ & $1 \cdot 5$ \\
\hline Myristic & $\mathrm{C} 14$ & $32 \cdot 0$ & $29 \cdot 1$ & $23 \cdot 5$ \\
\hline Palmitic & $\mathrm{Cl} 6$ & $6 \cdot 4$ & $7 \cdot 2$ & $7 \cdot 1$ \\
\hline $\begin{array}{l}\text { Hydroxy- } \\
\text { palmitic }\end{array}$ & $\mathrm{Cl}, \mathrm{OH}$ & $1 \cdot 4$ & $1 \cdot 2$ & $1 \cdot 3$ \\
\hline Stearic & $\mathrm{C} 18$ & $8 \cdot 5$ & $8 \cdot 6$ & $8 \cdot 1$ \\
\hline Oleic & $\mathrm{C} 18, \Delta 9$ & $8 \cdot 1$ & $17 \cdot 3$ & $10 \cdot 3$ \\
\hline Linoleic & $\mathrm{C} 18, \Delta 9,12$ & 6.9 & $6 \cdot 8$ & $18 \cdot 7$ \\
\hline $\begin{array}{l}\alpha \text {-Linolenic and } \\
\gamma \text {-linolenic }\end{array}$ & $\left.\begin{array}{l}C 18, \Delta 9,12,15 \\
C 18, \Delta 6,9,12\end{array}\right\}$ & $1 \cdot 2$ & $1 \cdot 4$ & $2 \cdot 2$ \\
\hline $\begin{array}{l}\text { Cyclopropano- } \\
\text { nonadecanoic }\end{array}$ & C19, cyclic & $25 \cdot 9$ & $19 \cdot 6$ & $18 \cdot 8$ \\
\hline Arachidic & $\mathrm{C} 20$ & $1 \cdot 2$ & $1 \cdot 1$ & $0 \cdot 8$ \\
\hline Arachidonic & $\mathrm{C} 20, \Delta 5,8,11,14$ & 1.9 & $2 \cdot 1$ & $1 \cdot 8$ \\
\hline Clupanodonic & $\mathrm{C} 22, \Delta 7,10,13,16,19$ & $1 \cdot 8$ & $1 \cdot 6$ & $2 \cdot 8$ \\
\hline Unidentified & & $3 \cdot 4$ & $2 \cdot 8$ & $3 \cdot 1$ \\
\hline
\end{tabular}

inhibitory effects through a lowering of $\mathrm{pH}$. However, strict regulation of conditions in all incubations make this unlikely.

It has been shown that micro-organisms meet their fatty acid requirements by different mechanisms, including uptake from their environment. Increased incorporation of long chain fatty acid results in alteration and damage to bacterial membranes and may also affect metabolic pathways, resulting in bacterial destruction. ${ }^{32}$ The growth inhibitory effect of unsaturated fatty acids on other organisms has long been recognised and the role of physicochemical properties, including isomerism and the degree of unsaturation, has been demonstrated in susceptible bacteria. ${ }^{17,33}$ Furthermore, studies have shown the importance of a free carboxyl group in the damaging effects of fatty acids and the negation of this by esterification with cholesteryl or methyl groups. ${ }^{17,33}$

Incorporation of linoleic acid resulted in reduction in the level of cyclopropano-nonadecanoic acid in $H$. pylori phospholipid. The synthesis of cyclic fatty acids and the activity of "desaturase"-which is involved in their production - are stimulated by hydrogen ions and inhibited by hydroxyl ions in other organisms, ${ }^{34}$ suggesting that this class of fatty acids may play a part in stabilising membranes against adverse $\mathrm{pH}$ levels. Cyclopropano-nonadecanoic acid is a significant constituent of $H$. pylori membranes and may be important in protecting the organism in an acidic environment. It is possible that factors that reduce the level of this fatty acid in vivo will render $H$. pylori more susceptible to damage by gastric acid.

The growth inhibitory effects of low concentrations of all three free fatty acids in this study were reversible. This indicates that, at these concentrations, they produced a bacteriostatic effect. Other studies have also shown that, in low concentrations, fatty acids produce a reversible inhibition of micro- organisms ${ }^{33,35}$ Lecithin, cholesterol, haemoglobin and horse serum are effective in reversing fatty acid inhibition. In this study the presence of horse serum in the fresh Brucella broth probably played a role in reversing the bacteriostatic effect. However, with the higher concentrations of fatty acids, inhibition of $H$. pylori growth was irreversible because of disruption of cell membranes and cell lysis.

The finding that oleic acid at low concentrations inhibited $H$. pylori growth within $24 \mathrm{~h}$, but by $48 \mathrm{~h}$ the bacteria had recovered and the growth rate had returned to normal, has been observed with other bacteria and is believed to be related to biotin metabolism. $^{33}$

The inhibitory effects of unsaturated fatty acids may arise by direct chemical action on bacterial metabolism. The formation of short chain aldehydes through oxidation of fatty acid double bonds has a toxic effect in a $\mathrm{pH}$-dependent manner. However, the concentrations of aldehydes required to produce damage are far greater than those detected in the presence of even the high concentrations of unsaturated fatty acids used, suggesting that this mechanism may not be important. An alternative theory, which is supported by our findings, is based on the physicochemical properties of the molecules. Long-chain unsaturated fatty acids are lipophilic to an extent, which is related to the cis/trans configuration as well as the degree of unsaturation. Adsorption of a monolayer of fatty acid to the bacterial cell surface may lead to incorporation of the fatty acid into the cytoplasmic membrane, resulting in alteration of membrane permeability. Low concentrations of fatty acids may reduce permeability. This will decrease the entry of essential nutrients and produce a bacteriostatic effect. Incorporation of larger amounts of fatty acid may produce an opposite effect and increase permeability leading to osmotic cell lysis and a bactericidal effect. 
In conclusion, this study demonstrated that unsaturated fatty acids were inhibitory to $H$. pylori growth in vitro. Inhibition was related to the concentration and degree of unsaturation of the fatty acid and was irreversible at high concentrations. The degree of growth inhibition was related to the incorporation of fatty acids into $H$. pylori phospholipid and was

\section{References}

1. Marshall BJ, Goodwin CS, Warren JR et al. Prospective doubleblind trial of duodenal ulcer relapse after eradication of Campylobacter pylori. Lancet 1988; 2: 1439-1442.

2. Graham DY. Campylobacter pylori and peptic ulcer disease. Gastroenterology 1989; 96: 615-625.

3. Tytgat GN, Noach L, Rauws EAJ. Helicobacter pylori. Scand J Gastroenterol 1991; 26 Suppl 187: 1-8

4. Wyatt JI, Rathbone BJ, Sobala GM et al. Gastric epithelium in the duodenum: its association with Helicobacter pylori and inflammation. J Clin Pathol 1990; 43: 981-986.

5. Carrick J, Lee A, Hazell S, Ralston M, Daskalopoulos G Campylobacter pylori, duodenal ulcer, and gastric metaplasia: possible role of functional heterotopic tissue in ulcerogenesis. Gut 1989; 30: 790-797.

6. Graham DY, Lew GM, Klein PD et al. Effect of treatment of Helicobacter pylori infection on the long-term recurrence of gastric or duodenal ulcer. A randomized, controlled study. Ann Intern Med 1992; 116: 705-708.

7. Hollander D, Tarnawski A. Dietary essential fatty acids and the decline in peptic ulcer disease - a hypothesis. Gut 1986; 27 : 239-242.

8. Grant HW, Palmer KR, Riermesma RR, Oliver MF. Duodenal ulcer is associated with low dietary linoleic acid intake. Gut 1990; 31 : 997-998.

9. Lamar RV. Chemo-immunological studies on localized infections; third paper; some further observations upon the action of certain soaps on the pneumococcus and its experimental infections. $J$ Exp Med 1911; 14: 256-264.

10. Kodicek E, Worden AN. The effect of unsaturated fatty acids on Lactobacillus helveticus and other gram-positive microorganisms. Biochem $J$ 1945; 39: 78-85.

11. Humfeld $H$. Antibiotic activity of the fatty-acid-like constituents of wheat bran. $J$ Bacteriol $1947 ; 54: 513-517$.

12. Coonrod JD, Lester RL, Hsu LC. Characterization of the extracellular bactericidal factors of rat alveolar lining material. $J$ Clin Invest $1984 ; 74: 1269-1279$

13. Kearney JN, Ingham E, Cunliffe WJ, Holland KT. Correlations between human skin bacteria and skin lipids. Br J Dermatol 1984; 110: 593-599.

14. Fuller R, Moore JH. The inhibition of growth of Clostridium welchii by lipids isolated from the contents of the small intestine of the pig. J Gen Microbiol 1967; 46: 23-41.

15. Morotomi M, Kawai Y, Mutai M. Intestinal microflora in rats: isolation and characterization of strictly anaerobic bacteria requiring long-chain fatty acids. Appl Environ Microbiol $1976 ; 31: 475-480$

16. Galbraith H, Miller TB. Physicochemical effects of long chain fatty acids on bacterial cells and their protoplasts. $J$ Appl Bacteriol 1973; 36: 647-658.

17. Kondo $E$, Kanai $K$. The relationship between the chemical structure of fatty acids and their mycobactericidal activity. Jpn J Med Sci Biol 1977; 30: 171-178.

18. Fay JP, Farias RN. The inhibitory action of fatty acids on the growth of Escherichia coli. J Gen Microbiol 1975; 91 : 233-240. accompanied by morphological changes and membrane disruption. This study has identified an area of $H$. pylori metabolism that is susceptible to manipulation and may, therefore, provide a focus for therapy.

S.K. was supported by an Astra Foundation Research Fellowship

19. Wang LL, Johnson EA. Inhibition of Listeria monocytogenes by fatty acids and monoglycerides. Appl Environ Microbiol $1992 ; 58: 624-629$

20. Nieman C. Influence of trace amounts of fatty acids on the growth of microorganisms. Bacteriol Rev 1954; 18: 147-163.

21. Raychowdhury MK, Goswami R, Chakrabarti P. Effect of unsaturated fatty acids in growth inhibition of some penicillin-resistant and sensitive bacteria. J Appl Bacteriol 1985; 59: 183-188.

22. Willett NP, Morse GE. Long-chain fatty acid inhibition of growth of Streptococcus agalactiae in a chemically defined medium. J Bacteriol 1966; 91 : 2245-2250.

23. Kodicek E. Further studies on the effect of linoleic acid on Lactobacillus casei. J Gen Microbiol 1958; 18: xiii.

24. Gill CO, Suisted JR. The effects of temperature and growth rate on the proportion of unsaturated fatty acids in bacterial lipids. J Gen Microbiol 1978; 104: 31-36.

25. Hampton MJ, Floyd RA, Bennett-Clark J, Lancaster JH. Studies of the fatty acid composition and membrane microviscosity in Salmonella typhimurium TA98. Chem Phys Lipids 1980; 27 : 177-183.

26. Henderson RJ, Millar R-M, Sargent JR, Jostensen J-P. Transmonoenoic and polyunsaturated fatty acids in phospholipids of a Vibrio species of bacterium in relation to growth conditions. Lipids 1993 28: 389-396.

27. Morgan DR, Freedman R, Depew CE, Kraft WG. Growth of Campylobacter pylori in liquid media. J Clin Microbiol $1987 ; 25: 2123-2125$.

28. Miles AA, Misra SS, Irwin JO. The estimation of the bactericidal power of the blood. $J$ Hyg $1938 ; 38$ : 732-748.

29. Folch J, Lees M, Sloane Stanley GH. A simple method for the isolation and purification of total lipides from animal tissues. J Biol Chem 1957; 226: 497-509.

30. Serrano de la Cruz D, Santillana E, Mingo A, Fuenmayor G, Pantoja A, Fernandez E. Improved thin-layer chromatographic determination of phospholipids in gastric aspirate from newborns, for assessment of lung maturity. Clin Chem 1988; 34: 736-738.

31. Morrison WR, Smith LM. Preparation of fatty acid methyl esters and dimethylacetals from lipids with boron fluoridemethanol. J Lipid Res 1964; 5: 600-608.

32. Hawke JC. The incorporation of long-chain fatty acids into lipids by rumen bacteria and the effect on biohydrogenation. Biochim Biophys Acta 1971; 248: 167-170.

33. Kodicek E. The effect of unsaturated fatty acids on grampositive bacteria. Symp Soc Exp Biol 1949; 3: 218-232.

34. Sinyak KM, Rudichenko VF, Yaroshenko MN, Kruk VI. Regulation of fatty acid composition of Clostridium perfringens type A cells by hydrogen and hydroxyl ions. Biol Bull Acad Sci USSR 1981; 8: 223-230.

35. Galbraith H, Miller TB, Paton AM, Thompson JK. Antibacterial activity of long chain fatty acids and the reversal with calcium, magnesium, ergocalciferol and cholesterol. $J$ Appl Bacteriol 1971; 34: 803-813. 